\title{
A PSYCHOPHYSICAL MODEL OF ACCEPTABLE NOISE LEVEL FROM A HUMAN SOUND PROCESSING PERSPECTIVE \\ Contributions:
} A Study design/planning B Data collection/entry C Data analysis/statistics D Data interpretation E Preparation of manuscrip F Literature analysis/search G Funds collection

\section{Bankole K. Fasanya ${ }^{\mathrm{A}-\mathrm{F}}$}

Environmental Health and Safety, Purdue University Northwest, Indiana, United States

Corresponding author: Bankole K. Fasanya, Environmental Health and Safety, College of Technology, Purdue University Northwest, 2200 169th Street, 46375, Hammond, Indiana, United States; email: fbankole@pnw.edu

\begin{abstract}
Background: Acceptable noise level (ANL) is a metric developed for quantifying the maximum amount of background noise one is willing and able to accept - when not tired or tensed - while involved in mundane work. ANLs have been shown to vary with the individual although they are generally independent of age, gender, and hearing sensitivity. This study develops a psychophysically based mathematical model of ANL that includes an individual's sound judgment bias and discriminability.

Material and methods: This paper expands Stevens' mathematical model of sound power to develop an explicit psychophysical model. The model includes an individual's judgment bias and sound discriminability to predict their ANL and uncovers the reason for individual ANL variability.

Results: Using simulated data, the developed model shows how an individual's ANL can be predicted based on their sound discriminability and judgment bias score. A regression analysis on the simulated data showed an $R$-square of $0.85(p=0.0001)$ between discriminability and simulated ANL data. There was a logarithmic relationship between individual ANL and sound discriminability.
\end{abstract}

Conclusions: The model well replicates human auditory sound processing. The higher the ANL, the higher the individual's judgment bias toward the background noise and the better their ability to discriminate between the signal and background noise.

Key words: noise • auditory nerve • sound discriminability • judgement bias score • psychophysics

\section{PSYCHOFIZYCZNY MODEL AKCEPTOWALNEGO POZIOMU SZUMU Z PERSPEKTYWY PRZETWARZANIA DŹWIĘKU PRZEZ CZŁOWIEKA}

\section{Streszczenie}

Wprowadzenie: Akceptowalny poziom szumu (ANL) jest miarą opracowaną do określenia maksymalnego poziomu szumu w tle, który dana osoba jest w stanie zaakceptować - gdy nie jest zmęczona lub spięta - podczas wykonywania rutynowych zadań. Wykazano, że ANL jest różny dla różnych osób, chociaż z zasady jest niezależny od wieku, płci i czułości słuchu. W niniejszym badaniu został opracowany matematyczny model ANL o podstawach psychofizycznych uwzględniający osobniczy błąd oceny dźwięków i zdolność ich rozróżniania.

Materiał i metody: Niniejsza praca rozwija matematyczny model siły dźwięku opracowany przez Stevensa w celu stworzenia modelu jednoznacznie psychofizycznego. Model ten, uwzględniając różnice dotyczące osobniczego błędu w zakresie oceny dźwięku i zdolności rozróżniania dźwięków, przewiduje ANL dla danej osoby i wskazuje przyczyny osobniczej zmienności ANL.

Wyniki: Opierając się na symulowanych danych, opracowany model pokazuje, że indywidualny ANL można przewidzieć na podstawie poziomu zdolności rozróżniania dźwięków i osobniczego błędu oceny. Analiza regresji przeprowadzona na symulowanych danych pokazała, że współczynnik determinacji między poziomem zdolności rozróżniania dźwięków a symulowanymi danymi wynosił $R^{2}=0,85(p=0,0001)$. Między indywidualnym ANL a zdolnością rozróżniania dźwięków występowała zależność logarytmiczna.

Wnioski: Model dobrze odzwierciedla słuchowe przetwarzanie dźwięków przez człowieka. Im wyższe ANL, tym większy osobniczy błąd oceny dźwięku na korzyść szumu tła i lepsza zdolność rozróżniania sygnału od szumu.

Słowa kluczowe: szum, nerw słuchowy, zdolność rozróżniania dźwięków, błąd oceny, psychofizyka

\section{Introduction}

A frequent complaint is difficulty in understanding speech in the presence of background noise [1]. Noise does not need to be at a high level to be annoying. Its effects can be detrimental to human physical health and to work performance. The impacts of noise are not limited to hearing loss, poor speech intelligibility [2], motivational and physiological effects [3], or stress and fatigue [4]. All these effects on human have been well documented in the literatures; as well as the anatomical and the psychophysical effects.
However, little attention has been given to how internal noise changes the impact of external noise on humans generally. Hearing and audiometric studies indicate that noise is a combination of internal and external sources. Noise from an internal source is known as internal noise and is generated by neural responses [5]. The neural responses determine the individual's internal judgments toward external noise. In this way, internal noise can affect an individual's judgment bias toward external noise. An individual's ability to tolerate external noise is controlled by noise familiarization. Apparently, even when there is no noise 
in the surroundings, there is still some internal noise in the individual's mind which is caused by constant internal nerve firing.

The auditory nerve is a collection of axons connecting the peripheral auditory system to auditory areas of the brain [6]. It is made up of approximately 30,000 to 55,000 nerve fibers depending on the species. About $95 \%$ of them are afferent, projecting from cell bodies in the cochlea to cochlear nuclei in the brainstem, and the rest are efferent, coming to the cochlea from cells in the olivary complex. Thus, the chance of detecting a signal in the presence of background noise depends on an individual's neural activity. Although external noise can be controlled, nothing can be done to control internal noise because internal noise is inherent in the human body. An individual's response to noise can best be studied by recording neural activity in the brain [5].

Schomer [7] defines external noise as environmental noise emitted from all sources except internally. External noise can be of different types and depends on the source, for example, white and pink noise from a radio, babble/multitasker noise from sports centers, speech spectrum noise from a talker, and so on. Major sources of environmental noise are roads, aircraft, railways, industry, construction, public works, neighborhood noise, etc.

The phenomenon of external noise acceptance by an individual can best be explained by a psychophysical study. In 1991, Nabelek and colleagues developed a model called Acceptable Noise Level (ANL) to quantify the maximum amount of background noise (external noise) one is willing and able to accept (in a specific period without being tensed or tired) while doing a mundane task [8]. Mathematically:

$\mathrm{ANL}=\mathrm{MCL}-\mathrm{BNL}$

where MCL is the Most Comfortable Listening level and BNL is the Background Noise Level. Thereafter, several authors have contributed to research on ANL. Some authors have concluded that there is a large inter-subject difference in the acceptance of background noise $[9,10]$. In 2003, Rogers and colleagues found no differences in ANL between genders [11]. In 2006, Harkrider \& Tampas reported that brain responses to noise were different for listeners with low ANLs than with high ANLs [12]. These findings provide good evidences that there is no difference in the judgment of background noise exhibited by individuals due to differences in physiological activity in the auditory system.

Psychophysically, before one can determine a listener's ANL, we need to recognise that hearing processes must go through several steps, starting from sensing the sound to deciding on the acceptable level for hearing. Initially, the human ear senses the sound and, based on the neural activity, the preferred sound level is determined. Concurrently, the listener discriminates between sound levels and selects the MCL. The human ear also filters background noise to determine the maximum BNL to accept at a particular time. However, the question remains, "What about internal noise?" According to Gaussian signal-detection theory, the variance of internal noise is constant, so that

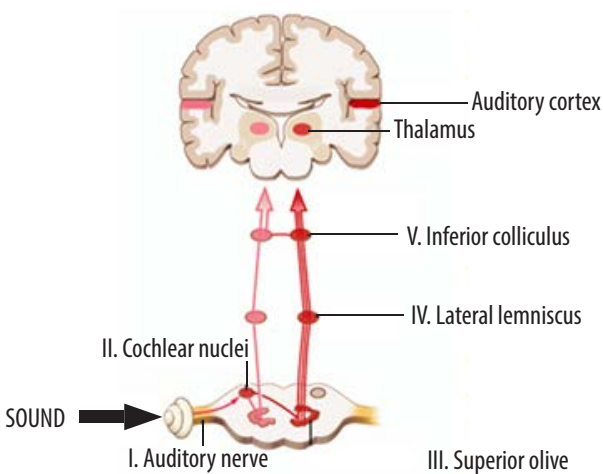

Figure 1. Central auditory processing [20]

it remains the same for all observations and does not vary over time [13]. Thus, the BNL and the MCL are two measures used to define a listener's ANL. The filtering process makes the human ear an extremely efficient filter bank as well as a highly sophisticated analogue to digital converter.

The brain processes this auditory signal. Auditory signal processes such as sound discrimination, association, memory, figure-ground, closure, sound bleeding, and attention take place at the Central Auditory Processing (CAP) in the brain. The entire process underlying the ANL metric is a result of the brain's interpretation of the signal and the noise. Mostly, ANL testing is done via air conduction and this is bilateral as well as unilateral. However, from the reception of sound signals in the cochlea to interpretation in the auditory cortex, the hearing process under any conditions is the same when it goes through CAP (see Figure 1). Crowley \& Nabelek found in 1996 that the central nervous system (CNS) contributed to the amount of background noise an individual is ready to accept when listening to continuous speech [14].

Freyaldenhoven \& Smiley [15] discuss Harkrider \& Tamper [12] who concluded in their study that the acceptance of noise might be mediated in the central regions of the nervous system of listeners with normal hearing. For example, stimuli mediation reduced ANLs significantly, but showed no effect on MCL in listeners with normal hearing. Harkrider \& Tamper [12] observed that reduction in ANL from stimulus mediation was not a result of peripheral auditory phenomena but occurred because of changes in auditory processing due to central nonauditory processes. Thus, the authors suggested that the physiological variations arising from central regions of the auditory system might have been mediated through an individual's background noise acceptance, which significantly reduced their ANL.

Harkrider \& Smith [16] described ANL in terms of human auditory discriminability, decision criterion, and noise familiarity. All these parameters as stated by Tucker are components of the auditory processing that occurs at the CAP in the brain [17]. Thus, individual ANL can be influenced by any of the parameters recognized by Tucker, and supporting the description by Harkrider \& Smith. Likewise, Ghosh \& Hemavathi concluded in their study that CAP difficulties might have led to the resolution difficulties experienced in individuals with varying degrees of 
ANL [18]. Psychophysical models have much to do with detecting simple differences or changes between sensory stimuli. Thus, psychophysical models can be used to identify the direction of changes in stimuli due to an individual bias toward the stimuli; how the directions are related is an important question for psychophysicists [19].

Therefore, psychophysical models that seek to understand the reasons for individual ANL variabilities might best explain the activities that occur in hearing pathways. Psychophysics relates just noticeable differences (changes) in stimuli to internal factors such as impulse response and human degree of sensitivity. In addition, psychophysical models [13] can best explain internal responses during discrimination tasks. The goal of this study is to develop a psychophysical and mathematical model, with CAP parameters based on Stevens' power law, in order to investigate why an individual's ANL variability depends on sound judgment bias and discriminability.

\section{Material and methods}

\section{Model development}

The model development began with sound detectability by using the signal detection theory (SDT), specifically developed for auditory processing by Kantowitz \& Sorkin [21]. In 2019, Fasanya [22] developed another model of human sound auditory processing based on the auditory processing model of [21] and signal detection theory. The Fasanya model relates sound discrimination, familiarization, and ANL together, and it forms the basis for the model developed here.

\section{Psychophysical model for ANL}

Psychophysics had begun over years to measure an individual's ability to detect threshold stimuli. Psychophysical model has been constantly adopting to understand the internal parameters involve in human auditory perception. In 2008, [19] used psychophysical model of auditory change perception to evaluate human detection in small change in stimuli. ANL approximates a psychophysical model of human auditory performance. In 1957, Stevens proposed a new law to relate sensation magnitude to stimulus intensity. Sensation is one of the human psychological auditory processing factors, which could be individual dependent and related to interest. The individual interest is based on the individual judgment bias toward a particular sound. Therefore, Stevens' power law, expressed in Equation 2 , is a good model from which a human psychophysical model for ANL can be developed.

$S=Q I^{\theta}$

where $Q$ is an arbitrary constant determining the scale unit), $\theta$ is a characteristic that indicates how fast the magnitude of the sensation grows as the stimulus intensity increases, $S$ is the sensation magnitude, and $I$ is the magnitude of the actual stimulus. Nabelek and colleagues [8] have used Equation 1 to quantify ANL mathematically. Stevens' law is considered as the most accepted psychophysics law for human auditory system [23]. Therefore, the two equations could be manipulated to develop a more robust psychophysical model for auditory system. Figure 2 represents the psychophysical graphical flow model developed and used in this study for sound processing. This figure shows that a sound wave enters human auditory system either through air or through bone conduction process and the sound goes through some processes within human auditory systems and to the brain before the ANL can be determined.

Therefore, using Stevens' power law in Equation 2, the psychophysical models for both the MCL and the BNL for sound processing based on Equation 2 can be expressed as:

$\mathrm{MCL}=f_{1}\left(\beta, d^{\prime}\right)=c_{1} d^{\prime}{ }_{1}^{\wedge}\left(\beta_{1}\right)$
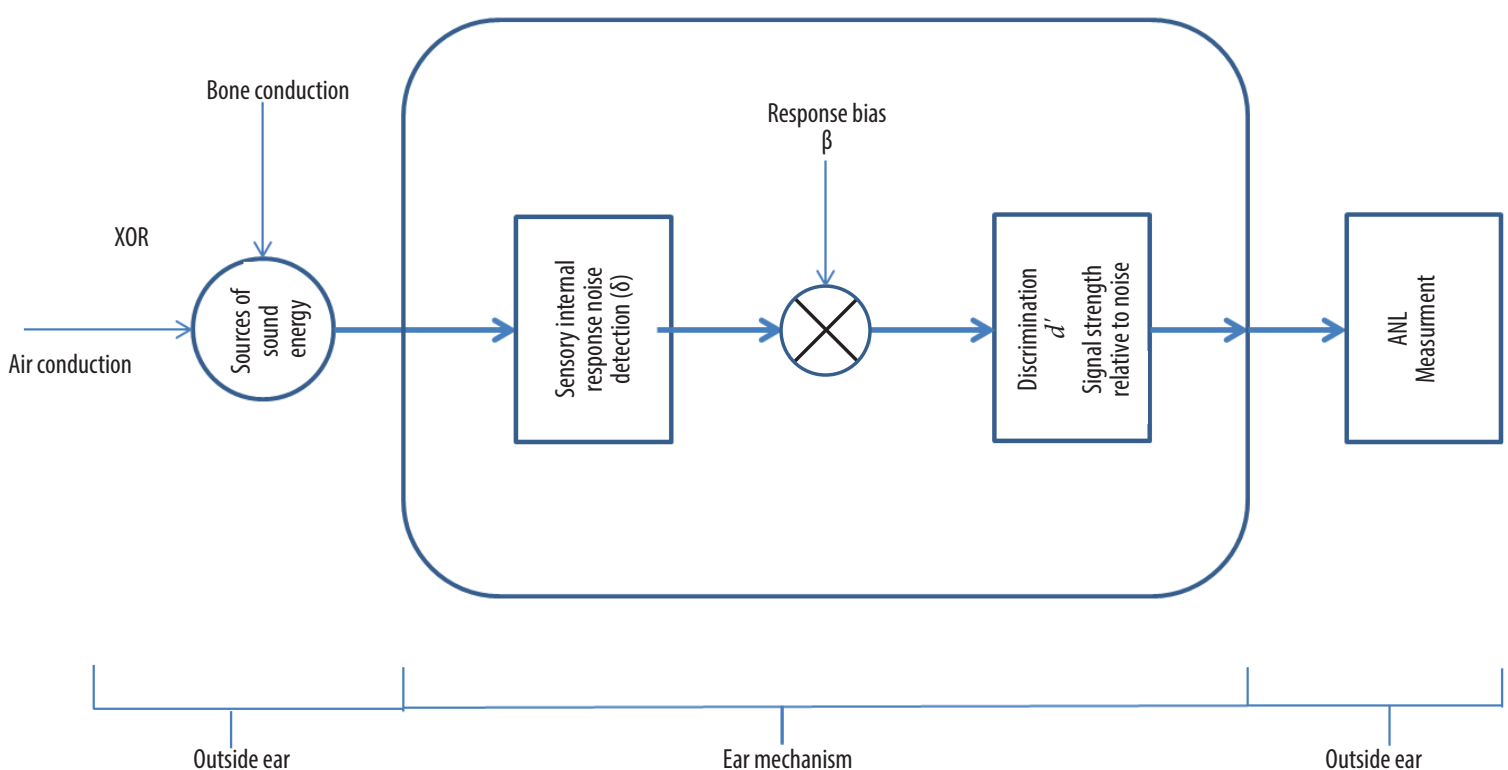

Figure 2. Psychophysical model for sound processing 
Table 1. ANOVA output of the regression result

\begin{tabular}{lccccc}
\hline & df & SS & MS & $\boldsymbol{F}$ & Significance of $\boldsymbol{F}$ \\
\hline Regression & 1 & 6832.227 & 6832.227 & 45.44434 & 0.000146 \\
\hline Residual & 8 & 1202.742 & 150.3427 & & \\
\hline Total & 9 & 8034.968 & & & \\
\hline
\end{tabular}

$\mathrm{BNL}=f_{1}\left(\beta, d^{\prime}\right)=c_{2} d_{2}^{\prime} \wedge\left(\beta_{2}\right)$

where $\beta_{i}(i=1,2)$ represents listener discriminability bias toward the sound intensity experienced, $d^{\prime}$ is the sound magnitude to be discriminated, and $c_{i}(i=1,2)$ is the constant of proportionality which can amplify or attenuate the magnitude of a sound stimulus.

Noting from Equation 1 that $\mathrm{ANL}=\mathrm{MCL}-\mathrm{BNL}$, then Equations 3 and 4 can be expressed as:

$\operatorname{ANL}\left(\beta, d^{\prime}\right)=f_{1}\left(\beta, d^{\prime}\right)-f_{2}\left(\beta, d^{\prime}\right)$

$\operatorname{ANL}(\beta, d)=c_{1} d^{\prime}{ }^{\prime} \wedge\left(\beta_{1}\right)-c_{2} d_{2}^{\prime} \wedge\left(\beta_{2}\right)$

Assume that $d_{1}^{\prime}{ }_{1}=d_{2}^{\prime}$, meaning that listeners have the same tendency to discriminate the noise and the signal level under a specific condition. Then when the signal is considered as MCL and noise as BNL, Equations 5 and 6 may be expressed as:

$\operatorname{ANL}\left(\beta, d^{\prime}\right)=c_{1} d^{\prime} \wedge\left(\beta_{1}\right)-c_{2} d^{\prime} \wedge\left(\beta_{2}\right)$

Taking log base 10 of both sides of Equation 7,

$\log \mathrm{ANL}=\left(\log c_{1}-\log c_{2}\right)+\left(\beta_{1}-\beta_{2}\right) \log d^{\prime}$,

and setting $\log c_{1}-\log c_{2}=\mathrm{C}$ and $\Delta \beta=\beta_{1}-\beta_{2}$, then

$\operatorname{ANL}\left(d^{\prime}, \beta\right)=10^{\wedge}\left(\mathrm{C}+\Delta \beta \log d^{\prime}\right)$.

This ANL psychophysical model indicates that under normal circumstances, if an individual's discriminability and judgement bias are known, then their ANL can be determined, and vice versa. That is, in order to solve for individual ANL in Equation 10, the psychophysical parameters for human discriminability and judgement bias must first be chosen. The value of $\operatorname{ANL}\left(d^{\prime}, \beta_{i}\right)$ in Equation 10 might be different from the ANL calculated from the experimental setting data. This could be the result of the difficulty in measuring human auditory judgement bias.

\section{Results}

The main purpose of this psychophysical model is to enable the prediction of ANL from individual judgement bias score and sound discriminability. This model was used to run simulated data that measured the relationship between ANL, judgement bias score, and discriminability. Figure 3 shows the relationship between the discriminability scores for a group of simulated data points and respective ANLs for the simulated data. This figure shows that the higher the individual auditory discriminability scores the higher the ANL, which means that the individual ability to discriminate between signal and noise is a good determinant of individual ANL. Psychologically, anyone with high discriminability is considered conservative and to be conservative means choosing more signal over noise.

Further, the theoretical data used to calculate the ANL was plotted against the ANL values to verify the validity of the model (see Figure 3). The curve in Figure 3 represents a logarithmic curve, which follows the same pattern as the human auditory sound processing curve. Additionally, a regression analysis was conducted on the simulated

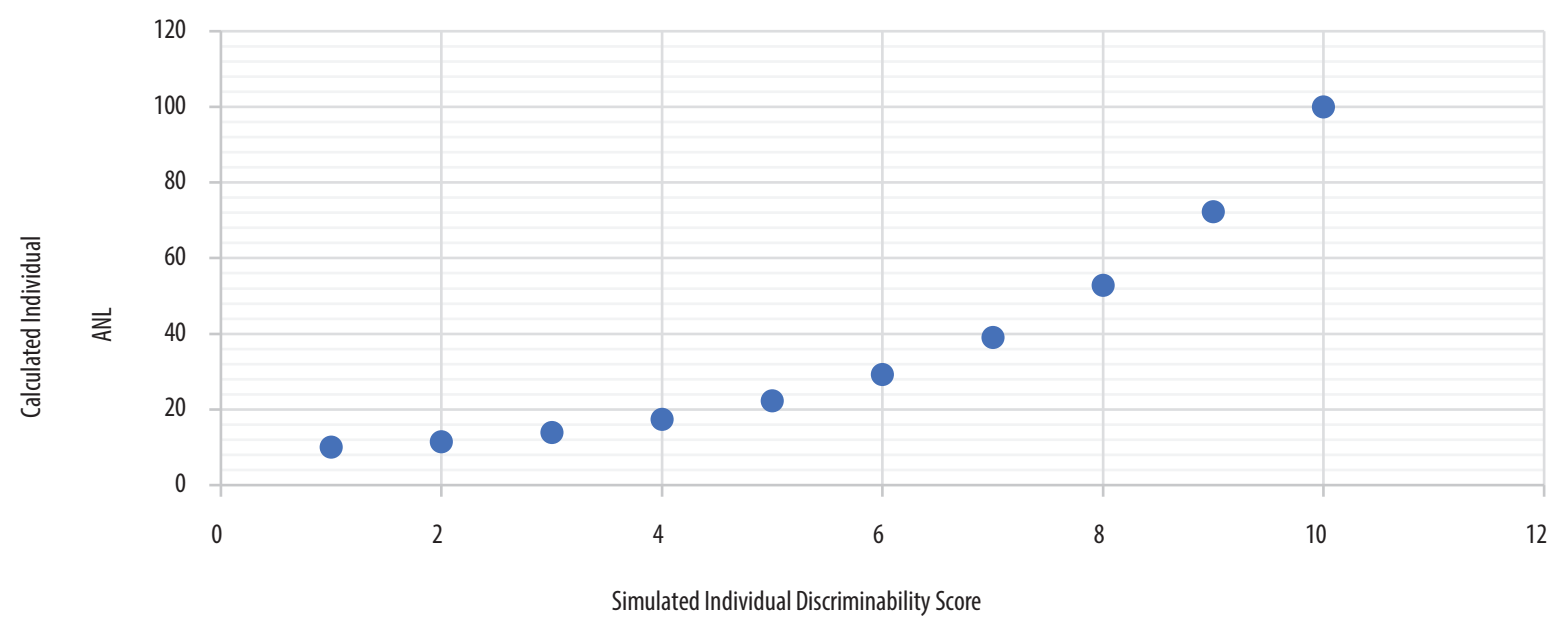

Figure 3 . ANL and Judgement Bias Scores relationship 
data, with $R$-square $=0.85$ and $p=0.0001$. Therefore, it can be concluded that the model well replicates human auditory sound processing. Table 1 shows the ANOVA output of the simulated data analysis. The higher the ANL, the higher the individual judgement bias toward the background noise and the better the individual ability to discriminate between background noise and signal. In this way, the precise generating mechanisms of this "fluctuating judgement bias" can be determined based on individual familiarity to the background noise. According to [22], familiarity significantly affect individual ability to discriminate between sounds.

\section{Discussion}

In the clinical arena, ANL has been found to be variable. Some authors have categorized their participants into low, mid, and high ANL variability [1,9]. Likewise, many researchers have reported inter- and intra-subject variability of ANL in listeners with normal hearing $[8,10]$. Additionally, findings from a study conducted on three subjects with normal hearing sensitivity revealed intrasubject variability [24]. In the test, the average standard deviation (SD) of the participant auditory thresholds within one session was $0.69 \mathrm{~dB}$ and was $0.87 \mathrm{~dB}$ when 10 threshold assessments were taken in a single day. Wertheimer noticed that the SD increased to $1.22 \mathrm{~dB}$ on average when measurements were taken daily over a period of 23 consecutive days [24]. The Wertheimer findings are also supported by Hawley and colleagues [25] findings. In fact, Hawley and colleagues conclude that the variability observed in pure tone thresholds over time could be influenced by several factors. Thus, the question remains, why the changes in individual sensitivity? Psychophysically, participant familiarization and sound judgment bias might influence individual loudness judgement and result in an increased standard deviation of sensitivity.

Findings in this area of research have also shown that signal-to-noise ratio (SNR) - the listener's ability to discriminate between the noise and the signal presented - has a significant effect on speech intelligibility for both hearing impaired listeners and normal listeners [26-28]. Therefore, high SNR can enhance ANL more than lower SNR. The low, mid, and high categorization, as well as the inter-subject variability in hearing sensitivity, again raise the question of why participant ANL varies. Should this be attributed to personality effects, body physiology, past exposure, age, gender, hearing sensitivity, or what? Crowley and Nabelek [14] present findings on how CNS can contribute to the amount of background noise that an individual is willing to accept while listening to continuous speech, and this is good evidence indicating that changes in familiarity can significantly affect inter-subject ANL variability.

Research has also shown that ANL is independent of age, hearing sensitivity, gender, and primary language of the listener $[10,28-30]$. Therefore, the factors resulting in variability are psychophysical factors. In this light, we should consider the findings of [16] who described ANL in terms of human auditory discriminability, decision criterion, and noise familiarity, as well as Tucker who concluded that the parameters mentioned by [16] in their study are components of auditory processing that occur at the CAP in the brain [17]. It is concluded that the mathematical relationship between the parameters could support better understanding on the variabilities in the individual ANLs.

Thus, this study provides some mathematical clarity about the relationship between individual discriminability and ANL. Simulated data revealed a logarithmic relationship between ANL and individual sound discriminability. Likewise, the regression analysis performed on the data further revealed that individual judgment bias is a good predictor of ANL. Harkrider \& Tamper [12] observed that ANL reduction stimuli mediation was not a result of peripheral auditory phenomena but occurred because of changes in auditory processing due to central non-auditory processes. In the study, Harkrider \& Tamper discovered that participant ANL reduced significantly but the MCL was not affected. This finding agrees with the model developed in this study.

\section{Limitations of the model}

This model is developed only for human auditory processing and can only be used where a subject's auditory judgement bias and discriminability score are known. It is not an experimentally based finding but a theoretical way of determining an individual's ANL. Likewise, human discriminability and judgement bias must first be chosen in order to solve for an individual's ANL using this model.

\section{Conclusion}

This study has investigated the mathematical relationship between individual judgement bias toward a particular noise, sound discriminability, and ANL. The mathematical model developed in this study reveals the reason for individual ANL variability and shows the relationship between some human auditory psychophysical parameters. The relationship enhances understanding of how judgement bias as well as familiarity improves ANL. The model has shown that an individual's judgment bias is a non-auditory processes parameter that can significantly influence the ANL. This means that if a person has low judgment bias toward a particular noise then they tend to accept a higher level of background noise and will still be comfortable in the environment. A mathematical simulation conducted with the model suggests that an individual ANL depends on the person's judgement bias and ability to discriminate between sounds under certain environmental conditions. This study has also shown that an individual's ANL has a logarithmic relationship with their ability to discriminate between signal and background noise. The logarithmic relationship demonstrates that the model well mimics auditory processing and could be used as psychophysical mathematical model for ANL.

It can be concluded that inter-subject variability noted in past studies are a result of individual judgement bias toward background noise and of their ability to discriminate between the presented signal and the background noise. As suggested in another study [18], that aspect of CAP evaluation may help in understanding the process-specific discrepancies in individual ANL variability. The findings from this study shed some light on the variabilities in terms of psychophysical parameters of the CAP. In future, more mathematical modelling will help to better 
understand the psychophysical parameters that contribute to individual ANL differences.

\section{Acknowledgements}

The author acknowledges the help of Ms Precious Fasanya during review of this manuscript and Dr Tomasz Letowski for inspiration and for encouragement to think outside the box.

\section{Declaration}

This study was not funded by any organization or agency.

\section{References}

1. Kattel BP, Fasanya BK, Letowski TR, Hargrove SK. The effect of types of background noise on the acceptable noise levels of individuals with normal hearing. In: Proceeding of the 13th Annual International Conference of Industrial Engineering, Las Vegas, NV, 2008.

2. Rao MD, Letowski T. Speech intelligibility of the Call Sign Acquisition Test (CAT) for army communication systems. Audio Engineering Society, 2003, 5836.

3. Maxwell EL, Evans WG. Design of childcare centers and effects of noise on young children. Minneapolis, IN: DesignShare 1999.

4. Valla AF, Sweetow RW. Psychology on individuals with hearing impairment. In: RE Sandlin, Textbook of Hearing Aid Amplification: Technical and clinical considerations, 2000 (2nd ed.), San Diego, CA, pp. 557- 70 .

5. Heeger D. Signal detection theory (lecture note). Retrieved August 23, 2020. Available from http://www.cns.nyu.edu/ david/ handouts/sdt-advanced.pdf; 1997.

6. Borisyuk A. Physiology and mathematical modeling of the auditory system. In: Tutorials in Mathematical Biosciences I. Springer, Berlin, 2005, pp. 107-68.

7. Schomer P. A White Paper: Assessment of Noise Annoyance. Champaign, IL, Schomer and Associates, 2001.

8. Nabelek AK, Tucker FM, Letowski TR. Toleration of background noises: relationship with patterns of hearing aid use by elderly persons. J Speech Hear Res, 1991; 34: 679-85.

9. Nabelek AK, Tampas JW, Burchfield SB. Comparison of speech perception in background noise with acceptance of background in aided and unaided conditions. J Speech Hear Res, 2004; 47: 1001-11.

10. Fasanya BK, Omotoso O, Fasanya OA. Effect of age on inter and intra-subject variability in acceptable noise level (ANL) in listeners with normal hearing. Management Sci Letters, 2013; 3(2), 385-94.

11. Rogers DS, Harkrider AW, Burchfield SB, Nabelek AK. The influence of listener's gender on the acceptance of background noise. J Am Acad Audiol, 2003; 14(7): 372-82.

12. Harkrider AW, Tampas JW. Differences in responses from the cochleae and central nervous systems of females with low versus high acceptable noise levels. J Am Acad Audiol, 2006; 17, 667-76.

13. Green DM, Swets JA. Signal Detection Theory and Psychophysics (vol. 1). New York, NY: Wiley 1966.

14. Crowley HJ, Nabelek IV. Estimation of client-assessed hearing aid performance based upon unaided variables. J Speech Hear Res, 1996; 39, 19-27.

15. Freyaldenhoven MC, Smiley DF. Acceptance of background noise in children with normal hearing. J Educational Audiol, 2006; 13, $27-31$
16. Harkrider AW, Smith SB. Acceptable noise level, phoneme recognition in noise, and measures of auditory efferent activity. J Am Acad Audiol, 2005; 16, 530-45.

17. Tucker DA. Central auditory processing. Department of Communication Sciences and Disorders, The University of North Carolina Greensboro, 2009.

18. Ghosh VPG, Hemavathi V. Temporal resolution of individuals with varying degrees of acceptable noise level. J Hear Sci, 2019; 9(2): 19-24.

19. Micheyl C, Kaernbach C, Demany, L. An evaluation of psychophysical models of auditory change perception. Psychological Review, 2008; 115(4), 1069-83.

20. Moore IB. Phillips R. Central auditory processing evaluations. clEarAudiology, PLLC. Retrieved October 29, 2020. Available from http://www.clearaudiology.com/central-auditory-processing-evaluations.html.

21. Kantowitz BH, Sorkin RD. Human Factors: Understanding people-system relationships. Toronto: Wiley, 1983.

22. Fasanya BK. Computational analyses of auditory discriminability using data from acceptable signal-to-noise ratio experiment. Intl J Human Factors Ergonomics, 2019; 6(2), 143-159.

23. Luce RD, Krumhansl C. Measurement, scaling, and psychophysics. In: Atkinson RC, Herrnstein RJ, Lindzey G, Luce RD (eds). Stevens' Handbook of Experimental Psychology, New York, NY; Wiley; 1988, pp. 1-74.

24 . Wertheimer M. The variability of auditory and visual absolute thresholds in time. J Gen Psychol, 1955; 52: 111-47.

25. Hawley ML, Sherlock LP, Formby C. Intra- and intersubject variability in audiometric measures and loudness judgments in older listeners with normal hearing. Semin Hear, 2017; 38(1), 3-25.

26. Adams EM, Moore RE. Effects of speech rate, background noise, and simulated hearing loss on speech rate judgment and speech intelligibility in young listeners. J Am Acad Audiol, 2009; 20(1), 28-39.

27. Schum D. Speech understanding in background noise. In: M. Valente (ed.), Hearing Aids: Standards, options, and limitations. NewYork: Thieme, 1996; pp. 368-406.

28. Killion MC. SNR loss: "I can hear what people say, but I can't understand them". Hearing Revolution Journal, 1997; 4(12), 8-14.

29. Tampas JW, Harkrider AW. Auditory evoked potentials in females with high and low acceptance of background noise when listening to speech. J Acoust Soc Am, 2006; 119: 1548-61.

30. Von Hapsburg D, Bahng J. Acceptance of background noise levels in bilingual (Korean-English) listeners. J Am Acad Audiol, 2006; 17: 649-58. 